\title{
Possible role of cysteine-S-conjugate $\beta$-lyase in species differences in cisplatin nephrotoxicity
}

\author{
Rieko Katayama $^{\text {a,b }}$, Saori Nagata ${ }^{\text {a }}$, Hiroko Iida ${ }^{a}$, Norio Yamagishi ${ }^{\text {b,c }}$, Tetsuro Yamashita ${ }^{\text {, }}$ \\ Kazuhisa Furuhama ${ }^{\text {a,b,* }}$
}

a Department of Veterinary Basic Medicine, Iwate University, Morioka, Iwate 020-8550, Japan

${ }^{\mathrm{b}}$ United Graduate School of Veterinary Sciences, Gifu University, Gifu, Gifu 501-1193, Japan

${ }^{\mathrm{c}}$ Department of Veterinary Clinical Medicine, Iwate University, Morioka, Iwate 020-8550, Japan

${ }^{\mathrm{d}}$ Department of Food Science and Biochemistry, Faculty of Agriculture, Iwate University, Morioka, Iwate 020-8550, Japan

*Corresponding author: Tel/fax: +81 196216213

E-mail address: furuhama@iwate-u.ac.jp

3-18-8 Ueda, Morioka, Iwate 020-8550, Japan (K. Furuhama)

Rieko Katayama: riekokt@mail.goo.ne.jp Saori Nagata: a1306010@iwate-u.ac.jp

Hiroko Iida: a1306012@iwate-u.ac.jp Norio Yamagishi: yamagisi@iwate-u.ac.jp

Tetsuro Yamashita: yamashit@iwate-u.ac.jp

Abbreviations: AOAA, Aminooxyacetic acid hemihydrochloride; AST/GOT, aspartate aminotransferase/ glutamate oxaloacetate transaminase; C-S lyase, cysteine-S-conjugate $\beta$-lyase; $\mathrm{IC}_{50}, 50 \%$ inhibitory concentration; PIXE, particle induced X-ray emission; PLP, pyridoxal 5'-phosphate; Pt, platinum. 


\section{Possible role of cysteine-S-conjugate $\beta$-lyase in species differences in cisplatin nephrotoxicity}

Rieko Katayama $^{\text {a,b }}$, Saori Nagata ${ }^{\text {a }}$, Hiroko Iida ${ }^{a}$, Norio Yamagishi ${ }^{\text {b,c }}$, Tetsuro Yamashita ${ }^{\text {, }}$, Kazuhisa Furuhama ${ }^{\text {a,b,* }}$

${ }^{a}$ Department of Veterinary Basic Medicine, Iwate University, Morioka, Iwate 020-8550, Japan

${ }^{\mathrm{b}}$ United Graduate School of Veterinary Sciences, Gifu University, Gifu, Gifu 501-1193, Japan

${ }^{\mathrm{c}}$ Department of Veterinary Clinical Medicine, Iwate University, Morioka, Iwate 020-8550, Japan

${ }^{\mathrm{d}}$ Department of Food Science and Biochemistry, Faculty of Agriculture, Iwate University, Morioka, Iwate 020-8550, Japan

*Corresponding author: Tel/fax: +81 196216213

E-mail address: furuhama@iwate-u.ac.jp

3-18-8 Ueda, Morioka, Iwate 020-8550, Japan (K. Furuhama)

Rieko Katayama: riekokt@mail.goo.ne.jp

Saori Nagata: a1306010@iwate-u.ac.jp

Hiroko Iida: a1306012@iwate-u.ac.jp

Norio Yamagishi: yamagisi@iwate-u.ac.jp

Tetsuro Yamashita: yamashit@iwate-u.ac.jp

Abbreviations: AOAA, Aminooxyacetic acid hemihydrochloride; AST/GOT, aspartate aminotransferase/ glutamate oxaloacetate transaminase; C-S lyase, cysteine-S-conjugate $\beta$-lyase; $\mathrm{IC}_{50}, 50 \%$ inhibitory concentration; PIXE, particle induced X-ray emission; PLP, pyridoxal 5'-phosphate; Pt, platinum.

\section{ABSTRACT}

To better understand species differences in cisplatin nephrotoxicity, we focused on renal cysteine-S-conjugate $\beta$-lyase (C-S lyase), which may play a crucial role in the metabolism of platinum (Pt)-cysteine conjugates. Aminooxyacetic acid hemihydrochloride (AOAA), an inhibitor of C-S lyase, reduced renal injuries due to cisplatin in rats, suggesting involvement of C-S lyase. On day 5 following a bolus cisplatin injection, three species showed in vivo nephrotoxic potentials in the order of rats $>$ mice $=$ rabbits (the highest to lowest), based on body surface. The levels of renal Pt residue at the nephrotoxic dose were in order of rabbits $>$ rats $>$ mice. Meanwhile, the activity of endogenous (basal) mitochondrial aspartate aminotransferase (AST), one of the C-S lyases, in the renal cortex of naive animals was rats > 
mice $=$ rabbits. In a qualitative Western blot analysis, expression of mitochondrial C-S lyase in the kidney was observed at approximately $37 \mathrm{kDa}$ in all five species used. In in vitro studies, the cytotoxicity of cisplatin was dependent on the expression level of C-S lyase mRNA in the respective renal cells. These results demonstrate that species differences in cisplatin nephrotoxicity are attributable to an interaction of renal Pt transition with C-S lyase activity.

Keywords:

Cisplatin

Cysteine-S-conjugate $\beta$-lyase

Nephrotoxicity

Platinum

Species difference

\section{Introduction}

Platinum $(\mathrm{Pt})$ chemotherapeutic agents are essential in the treatment of a variety of malignant tumors including germ cell tumors (Giaccone 2000; Lokich and Anderson 1998). However, the widespread use of their derivative cisplatin (cis-diamminedichloroplatinum II) has been hampered mainly by its nephrotoxic potential (Cyitkovic 1998; Pinzani et al. 1994). The primary mechanism underlying cisplatin nephrotoxicity remains controversial (Hanigan et al. 2009; Wainford et al. 2009). In a series of papers, Hanigan and coauthors reported that the Pt-cysteine S-conjugate was converted to a toxic, highly reactive Pt-thiol by any of the several enzymes that catalyze the cysteine-S-conjugate $\beta$-lyase (C-S lyase) reactions (Hanigan and Devarajan 2003; Townsend and Hanigan 2002; Zhang et al. 2006; Zhang and Hanigan 2003). In contrast, Wainford et al. (2008) demonstrated that the inhibition of gamma-glutamyl transpeptidase (GGT) was able to protect against cisplatin nephrotoxicity, whereas the inhibition of C-S lyase was not. The main disagreement between the studies is the contribution of C-S lyase to cisplatin nephrotoxicity, as both agree that the first stage in the metabolic conversion of cisplatin to a nephrotoxin involves the formation of glutathione conjugates. However, because the experimental data presented by Wainford et al. (2008) were unlikely to address their hypothesis as mentioned above, we focused attention on the role of C-S lyases in cisplatin nephrotoxicity from the viewpoint of species difference. 
The C-S lyases contain pyridoxal 5'-phosphate (PLP) as a coenzyme, are present in both the cytosol and mitochondria, catalyze aminotransferase, and compete with the $\beta$-elimination reactions. At least 11 mammalian C-S lyases have been reported (Cooper and Pinto 2006). Renal aspartate aminotransferase (AST) belongs to the C-S lyases, and glutamate oxaloacetate transaminase (GOT) is another name of AST (Cooper et al. 2002).

Since we have investigated interspecies diversities in toxicities induced by various pharmaceutical agents so far (Kai et al. 2006; Sagara-Ishijima and Furuhama 1999; Tsuchiya et al. 2003), we are interested in species differences in renal C-S lyase to better understand cisplatin nephrotoxicity. In the present study, we first confirmed the involvement of C-S lyase in cisplatin-induced renal injury in rats by administering cisplatin alone or in combination with the C-S lyase inhibitor aminooxyacetic acid (AOAA). According to Townsend and Hanigan (2002), AOAA (three oral doses of $100 \mathrm{mg} / \mathrm{kg}$ ) protected against cisplatin nephrotoxicity in mice, but had no effect on Pt accumulation in the kidney. Additionally AOAA did not affect the uptake of the parent compound, cisplatin, into the mouse kidney. Next, we determined the nephrotoxic dose of cisplatin and renal Pt residue in mice, rats and rabbits given a bolus intravenous injection of cisplatin. As an indicator of the C-S lyase activity, the endogenous (basal) mitochondrial AST activity was measured in the renal cortex of naive mice, rats, rabbits, cats and dogs, and a qualitative Western blot analysis of C-S lyase was performed. In in vitro studies, the C-S lyase mRNA expression levels of intact cells originating from the kidneys of rats, rabbit, cats, and dogs were determined by real-time PCR, because spectrophotometric methods cannot be used to detect ALT activity due to low sensitivity. As an index of the cytotoxicity, a $50 \%$ inhibitory concentration $\left(\mathrm{IC}_{50}\right)$ was determined by exposure of these cells to cisplatin. Finally, we assessed the protective effect of AOAA against cytotoxicity of cisplatin at an $\mathrm{IC}_{50}$.

\section{Materials and Methods}

\subsection{Chemicals}

Cisplatin injections were purchased from Maruko Pharmaceutical (Aichi, Japan), and aminooxyacetic acid hemihydrochloride (AOAA) was from Wako Pure Chemical Industries (Osaka, Japan). All other chemicals and reagents were of the highest grade commercially available, unless otherwise stated.

\subsection{In vivo studies}

All animal manipulations were performed in accordance with the Guidelines for Animal Experimentation issued by the Japanese Association for Laboratory Animal Science (1987) and approved by the Animal Experimental Ethics Committee of Iwate University (Morioka, Japan). 
Male BALB/cCrSlc mice aged 6 weeks, male Fischer 344 (F344) rats aged 9 weeks, and male New Zealand White (NZW) rabbits aged 15 weeks were provided by Japan SLC (Shizuoka, Japan), and studies began after an acclimation period of at least 2 days. Five mice or 2 rats per plastic cage, and one rabbit per stainless-steel cage were housed in an air-conditioned facility (a temperature of $22 \pm 3^{\circ} \mathrm{C}$, a relative humidity of $55 \pm 25 \%$, and lighting at 8:00 AM to 8:00 PM with a 12-h light cycle). Mice and rats were given commercial rodent chow (MEQ, Oriental Yeast, Tokyo, Japan), rabbits were fed solid chow (Lab R stock, Nosan, Kanagawa, Japan), and all animals were given tap water ad libitum.

To confirm the involvement of renal C-S lyase in cisplatin nephrotoxicity, AOAA (100 mg/kg) was orally administered by gavage twice to groups of five F344 rats each 30 and 60 min before a bolus injection of cisplatin $\left(45 \mathrm{mg} / \mathrm{m}^{2}\right)$. Cisplatin was used as provided $(0.5 \mathrm{mg} / \mathrm{ml})$, and AOAA was dissolved in distilled water to be a concentration of $1 \%$. The dose for each agent was expressed in terms of the free base. The dose of AOAA was selected on the basis of the mouse data ( 3 oral doses of $100 \mathrm{mg} / \mathrm{kg}$ ) reported by Townsend and Hanigan (2002) and the result of our rat preliminary study (2 oral doses of 50 or 100 $\mathrm{mg} / \mathrm{kg}$ ) showing the protective action on cisplatin-induced renal injuries. The animals given $0.9 \%$ physiological saline (saline, $10 \mathrm{ml} / \mathrm{kg}$, iv) and distilled water $(10 \mathrm{ml} / \mathrm{kg}$, po) in the same way served as the vehicle control $(n=5)$. The first day of dosing was regarded as day 1 for this study. On day 5, blood was withdrawn from the cervical vein of the surviving animals under ether anesthesia, and the animals were euthanized by exsanguination. Serum creatinine concentrations were measured with an autoanalyzer (Hitachi, Tokyo). After necropsy, the right kidney was excised, fixed in $10 \%$ buffered formalin, embedded in paraffin wax, cut at 3- $\mu \mathrm{m}$ thickness, stained with hematoxylin and eosin (H-E), and histopathologically examined. The histological evaluation was conducted in a blinded manner. The cortex $(0.1 \mathrm{~g})$ of the left kidney was freeze-dried overnight, weighed, mixed with concentrated nitric acid at a ratio of 1:10, and placed on a hotplate at $100^{\circ} \mathrm{C}$ for $1-2 \mathrm{~h}$ to dissolve and evaporate. Then, $1 \mathrm{M}$ nitric acid was added, and the quantification of cortical Pt concentrations was performed using a particle induced X-ray emission (PIXE) method with a small cyclotron (baby cyclotron) established for positron nuclear medicine at the Nishina Memorial Cyclotron Center (Shizukuishi, Japan). The unit was represented as $\mu \mathrm{g} / \mathrm{g}$ dry weight of the renal cortex.

To identify the nephrotoxic dose in each species, cisplatin was intravenously administered once to mice (at 22.5, 45, and $90 \mathrm{mg} / \mathrm{m}^{2}, \mathrm{n}=5$ ), to rats (at 11.3, 22.5, 45, and $90 \mathrm{mg} / \mathrm{m}^{2}, \mathrm{n}=5$ ), or to rabbits (at 12, 24, 48, 96 and $192 \mathrm{mg} / \mathrm{m}^{2}, \mathrm{n}=3$ ). During the 5-day study period, death and survival was noted, and serum creatinine concentration, renal pathology, and renal cortical Pt concentration were also determined according to the aforementioned procedures.

To determine endogenous (basal) mitochondrial AST activity in the renal cortex of naive (untreated) animals, healthy mice, rats and rabbits were purchased from the providers listed above. Additionally, male and female laboratory cats aged $1-3$ years $(3.1 \pm 0.3 \mathrm{~kg})$ and male beagle dogs aged 2-3 years $(12.5 \pm 0.8$ $\mathrm{kg}$ ) were selected from among non-treated or control animals $(\mathrm{n}=5-6)$ in other projects. Since the 
mitochondrial AST was reported to catalyze the bioactivation of cisplatin and to transfect into renal cells (Zhang et al., 2006), this enzyme was selected among the C-S lyases. The mitochondrial AST activity was measured by a previously reported method (Cooper and Meister 1985) with some modifications. In brief, the renal cortex $(c a, 0.5 \mathrm{~g})$ from each animal was mixed with four volumes of $10 \mathrm{mM}$ Tris- $\mathrm{HCl}(\mathrm{pH} 7.5)$ containing 0.25 M sucrose (buffer) and one-tenth volume of protease inhibitor cocktail tablets (Complete Mini, Roche Diagnostics, Mannheim, Germany). They were homogenized using an auto-homogenizer (Polytron ${ }^{\circledR}$, Kinematica AG, Lucerne, Switzerland), and centrifuged at $600 \mathrm{~g}$ for $10 \mathrm{~min}$ at $4^{\circ} \mathrm{C}$. The supernatant was centrifuged again at $6,000 \mathrm{~g}$ for $20 \mathrm{~min}$ at $4{ }^{\circ} \mathrm{C}$. The resultant precipitates (pellets) were well suspended in approximately $1 \mathrm{ml}$ of the buffer, and then homogenized using a Teflon-lined homogenizer. This preparation was used as the mitochondrial fraction. This fraction was sonicated by using a Bioruptor (Cosmo Bio, Tokyo, Japan) for 5-10 min, followed by centrifugation at 20,400 g for 10 min. The protein concentration was quantified using a BCA protein assay kit (Pierce, Rockford, IL, USA), and the specimens were stored at $-80^{\circ} \mathrm{C}$ until assayed. To measure mitochondrial AST activities, a $50-\mu 1$ reaction mix containing the fraction $(40 \mu \mathrm{g}), 1 \mathrm{M}$ Tris- $\mathrm{HCl}(\mathrm{pH} 8.8,5 \mu \mathrm{l}), 50 \mathrm{mM}$ $\alpha$-keto- $\gamma$-methiolbutyrate $(\alpha-\mathrm{KGM})$, and $0.2 \mathrm{M}$ phenylalanine was incubated at $37^{\circ} \mathrm{C}$ for $30 \mathrm{~min}$, after which the reaction was stopped with addition of $1 \mathrm{M} \mathrm{KOH}(150 \mu \mathrm{l})$. The absorbance of phenyl-pyruvate formed was measured at $332 \mathrm{~nm}$, and the amount was calculated using its molar absorption coefficient.

For Western blot analysis of mitochondrial C-S lyases in naive animals, a constant protein amount (20 $\mu \mathrm{g}$ ) of the respective fraction samples was subjected to $12.5 \%$ SDS-PAGE, and the separated proteins were transferred to a hydrophobic polyyinylidene difluoride (PVDF) membrane (Immobilon ${ }^{\mathrm{TM}}-\mathrm{P}$, Millipore, Billerica, MA, USA). The membrane was incubated overnight in blocking buffer (Odyssey ${ }^{\circledR}$ Infrared Imaging System Blocking Buffer, LI-COR Biosciences, Lincoln, NE, USA) at $4^{\circ} \mathrm{C}$, and then incubated with the mouse anti-human antibody A01 (Abnova, Taipei, Taiwan) diluted 1:500 with Can Get Signal ${ }^{\circledR}$ Immunoreaction Enhancer Solution 1 (Toyobo, Osaka, Japan) for $1 \mathrm{~h}$ at room temperature. After being washed with Tris-buffered saline containing 0.05\% Tween 20 (TBS-T), the membrane was incubated with IRDye-labeled anti-mouse IgG secondary antibody (Rockland Immunochemicals, Gilbertsville, PA, USA) diluted 1:5000 with Can Get Signal ${ }^{\circledR}$ Immunoreaction Enhancer Solution 2 (Toyobo) for $1 \mathrm{~h}$ at room temperature in a box shielded from the light. The membrane was washed again, and the immunoreactive proteins were visualized using an Odyssey Infrared Imaging System (Odyssey ${ }^{\circledR}$ Infrared Imager, LI-COR Biosciences). The 3 independent experiments were performed on Western blot analysis.

\subsection{In vitro studies}

Normal rat kidney (NRK), rabbit kidney 13 (RK 13) and Medin-Darby canine kidney (MDCK) cell-lines (cells) were provided from Riken Research (Tokyo, Japan). Primary cultured cells from feline 
kidney distal tubules (FKD) were immortalized by transfection with pSV3neo plasmid (ATCC, Manassas, VA, USA) containing SV40 large T-antigen. All cells were cultured in Minimal Essential Medium (MEM, Nissui Pharmaceutical, Tokyo) with 1-10\% fetal bovine serum (FBS) or MEM containing 10\% FBS and non-essential amino acids (NEAA, GIBCO, NY) at $37^{\circ} \mathrm{C}$ in $5 \% \mathrm{CO}_{2}$. Cells were passaged every 3-4 days, using $0.1 \%$ trypsin. The 3 independent experiments were performed.

Total RNA isolated from the cells was used for reverse transcription and as a template from cDNA synthesis using oligo(dT) primers and a SuperScript First-Strand Synthesis System (Invitrogen, Carlsbad, CA). Real-time PCR was carried out in a thermal cycler (Real Time System TP 850, Takara Bio, Tokyo) using primers listed in Table 1. The glyceralddehyde-3-phosphate dehydrogenase (GAPDH) mRNA level was used as an internal control to normalize the amount of mRNA in the samples.

The cytotoxic potential of cisplatin was evaluated by incubating cells $\left(1 \times 10^{4}\right.$ cells, $\left.n=5-6\right)$ of each species with cisplatin $(3.13-400 \mu \mathrm{M})$ diluted with conditioned MEM medium containing $1 \% \mathrm{FBS}$ at $37^{\circ} \mathrm{C}$ for $3 \mathrm{~h}$. Then the medium was replaced with fresh conditioned medium, and the cells were incubated for $21 \mathrm{~h}$. The $\mathrm{IC}_{50}$ was calculated from survival rates (WST-1 assay) of cisplatin-treated cells compared with the respective vehicle controls. The WST-1 assay was performed by a cell counting kit (Dojindo, Kumamoto, Japan) according to the manufacturer's protocol. In brief, this assay is based on the measurement of the Formazan dye that is liberated after the cleavage of this reagent by mitochondrial dehydrogenase activity in viable cells. The cells exposed to cisplatin were then incubated with WST-1 reagent for $20 \mathrm{~min}$ at $37^{\circ} \mathrm{C}$. The staining intensity in the medium was measured by determining the absorbance at $450 \mathrm{~nm}$, and the data were expressed as ratios of the control value.

The protective effect of AOAA against cisplatin-cytotoxicity was examined by incubating cells with AOAA $(25-100 \mu \mathrm{M})$ and the appropriate $\mathrm{IC}_{50}$ of cisplatin dissolved in the conditioned MEM medium at $37^{\circ} \mathrm{C}$ for $30 \mathrm{~min}$. Then the medium was replaced with fresh conditioned medium, and the cells were incubated for $24 \mathrm{~h}$. The survival rates were determined by the WST-1 assay. Cells exposed to the conditioned medium alone under the same conditions served as the vehicle control $(n=4-6)$.

\subsection{Statistical analysis}

Quantitative data are expressed as means \pm standard deviation (SD). Statistical comparisons between two groups were performed by analysis of variance by $F$-test, followed by Student's $t$-test. Differences among three groups were compared using one-way ANOVA and Dunnett's test. A $P$ value of $<0.05$ was considered statistically significant.

\section{Results}

\subsection{Protective effects of AOAA against cisplatin nephrotoxicity in rats in vivo}


In rats given intravenously cisplatin $\left(45 \mathrm{mg} / \mathrm{m}^{2}\right)$ alone, one animal showing severe depression died on day 2. In surviving mice, marked increases in serum creatinine were noted with decreased body weight and extensive tubular necrosis, loss of the epithelial brush-border, pyknosis in the renal proximal epithelia, and the presence of casts in the lumen on day 5 (Table 2, Fig. 1A). In all rats receiving oral AOAA (100 $\mathrm{mg} / \mathrm{kg}$ ), toxic signs included decreases in locomotor activity, lateral recumbency, collapse, hyperemia of the legs and polyuria around $1 \mathrm{~h}$ after treatment, but completely recovered by day 2 . Neither change in serum creatinine nor morphology on day 5 was observed in the AOAA-alone group. Pretreatment with AOAA clinicopathologically ameliorated renal alterations induced by cisplatin alone. No death was observed during the study period in the cisplatin + AOAA group (Table 2, Fig. 1B).

No difference in cortical Pt residue was noted between the cisplatin-alone and cisplatin + AOAA groups (Table 2).

\subsection{Nephrotoxic dose of cisplatin in mice, rats and rabbits}

The findings in three species given intravenously cisplatin alone are shown in Table 3. No difference in morphological characteristics of cisplatin nephrotoxicity was observed among the 3 species.

In mice, no changes in serum creatinine and renal morphology were seen at $22.5 \mathrm{mg} / \mathrm{m}^{2}$. At $45 \mathrm{mg} / \mathrm{m}^{2}$, a tendency to increase serum creatinine concentration was noted with decreased body weight and slight to mild necrosis in the proximal epithelia. At $90 \mathrm{mg} / \mathrm{m}^{2}$, two mice died, and three surviving mice displayed decreased body weight and high serum creatinine with mild necrosis in the proximal epithelia. The increase in cortical Pt residue was less than proportional to the increase in the cisplatin dose, and the mean Pt concentration at the nephrotoxic dose $\left(45 \mathrm{mg} / \mathrm{m}^{2}\right)$ was $16.0 \mu \mathrm{g} / \mathrm{g}$.

In rats, no clinicopathological changes were seen at $11.3 \mathrm{mg} / \mathrm{m}^{2}$. At $22.5 \mathrm{mg} / \mathrm{m}^{2}$ or more, significantly increased serum creatinine was observed with decreased body weight and moderate necrosis in the proximal epithelia. At $90 \mathrm{mg} / \mathrm{m}^{2}$, all rats died by day 5 . The increase in cortical Pt residue was nearly proportional to the increase in the cisplatin dose, and the mean Pt concentration at the nephrotoxic dose $\left(22.5 \mathrm{mg} / \mathrm{m}^{2}\right)$ was $26.8 \mu \mathrm{g} / \mathrm{g}$.

In rabbits, no changes were seen at $24 \mathrm{mg} / \mathrm{m}^{2}$ or less. At $48 \mathrm{mg} / \mathrm{m}^{2}$ or more, a tendency to increase serum creatinine was observed with decreased body weight and mild to severe necrosis in the proximal epithelia. At $192 \mathrm{mg} / \mathrm{m}^{2}$, all rabbits died on day 1. The cortical Pt residue tended to increase more or less proportionally escalating doses of up to $96 \mathrm{mg} / \mathrm{m}^{2}$, and the mean Pt concentration at the nephrotoxic dose $\left(48 \mathrm{mg} / \mathrm{m}^{2}\right)$ was $81.7 \mu \mathrm{g} / \mathrm{g}$.

3.3. Renal mitochondrial AST activity and Western blot analysis of renal C-S lyase in naive mice, rats, rabbits, cats and dogs 
Mitochondrial AST activity was significantly higher in rats (mean: $29.5 \mathrm{nmol} / \mathrm{min} \cdot \mathrm{mg}, P<0.05$ ) and cats $(31.4 \mathrm{nmol} / \mathrm{min} \cdot \mathrm{mg}, P<0.05)$ than in mice $(9.2 \mathrm{nmol} / \mathrm{min} \cdot \mathrm{mg})$ and rabbits $(8.0 \mathrm{nmol} / \mathrm{min} \cdot \mathrm{mg})$. The AST activity $(18.8 \mathrm{nmol} / \mathrm{min} \cdot \mathrm{mg}, P<0.05)$ in dogs was mid-range among the five species (Fig. 2A). Western blot analysis (Fig. 2B) revealed expression of GOT2, at approximately $37 \mathrm{kDa}$, in all five species.

3.4. Expression of C-S lyase mRNA and cytotoxic potential of cisplatin in cells

After normalization to the GAPDH mRNA level, the C-S lyase mRNA level was significantly lowest in rabbit cells among the 4 cells tested (Fig. 3A). The $\mathrm{IC}_{50}$ of cisplatin was measured to be $95 \mu \mathrm{M}$ for rat cells, $180 \mu \mathrm{M}$ for rabbit cells, $10 \mu \mathrm{M}$ for cat cells and $16 \mu \mathrm{M}$ for dog cells (Fig. 3B). The cytotoxic potential was significantly weakest in rabbit cells among the 4 cells.

\subsection{Protective effect of AOAA against cisplatin cytotoxicity in vitro}

No protective effect of AOAA against cisplatin cytotoxicity was noted in either rat, cat or dog cells (data not shown). In rabbit cells, however, AOAA reversed cisplatin-induced decreases in the survival rate at a concentration as low as $25 \mu \mathrm{M}$ (Fig 4).

\section{Discussion}

Although the ability of the C-S lyase inhibitor AOAA to protect cisplatin nephrotoxicity has been shown in mice, no studies have reported this in rats (Hanigan et al. 2009). In the present investigation, we administered intravenous cisplatin $\left(45 \mathrm{mg} / \mathrm{m}^{2}\right.$ corresponding to $7.5 \mathrm{mg} / \mathrm{kg}$, FDA-CDER Guidance 2005) alone or in combination with oral AOAA to male F344 rats under the conscious conditions. The intravenous injection of cisplatin was selected based on the clinical route for humans and companion animals. Male F344 rats were chosen because of their high susceptibility to nephrotoxicant (Tarloff et al. 1989). AOAA clinicopathologically ameliorated cisplatin nephrotoxicity (Table 2), as was the case in male C57BL/6 mice (Townsend and Hanigan 2002), although the rats receiving AOAA exhibited severe clinical signs on day 1 . The renal Pt residue on day 5 did not differ between the cisplatin-alone and cisplatin + AOAA groups, demonstrating that elimination processes of cisplatin via the organic cation transporters, especially OCT2 (Ludwig et al. 2004) may not be disturbed by pretreatment with AOAA. Cisplatin conjugates with reduced glutathione (GSH), cysteinyl-glycine and $N$-acetyl-L-cysteine (NAC) have not been identified in the proximal tubular epithelia of the rat. Nevertheless, based on ameliorative features in cisplatin-treated rats given NAC (Dickey et al. 2008; Dickey et al. 2005), it has been proposed 
that cisplatin nephrotoxicity in rats also occurs via loss of free intracellular GSH, or through cellular biotransformation of cisplatin into toxic metabolites. Thus, it was considered that the onset of cisplatin nephrotoxicity in rats involved, at least in part, renal C-S lyase. Under our experimental status, although AOAA did not completely block cisplatin nephrotoxicity, no death was noted in the combined treatment, and alterations in renal morphology was apparently attenuated, suggesting that AOAA inhibited renal injury induced by a relatively high nephrotoxic dose of cisplatin. Our results contradicted the report of Wainford et al. (2008); however, their experimental conditions, including administration routes and regimens, were very different from ours. Regarding the rabbit study, since AOAA showed extremely severe clinical signs in rats as the aforementioned description, we could not carry out it from the viewpoint of the animal right.

Based on clinicopathological changes, the nephrotoxic dose was determined to be $45 \mathrm{mg} / \mathrm{m}^{2}$ for mice, $22.5 \mathrm{mg} / \mathrm{m}^{2}$ for rats, and $48 \mathrm{mg} / \mathrm{m}^{2}$ for rabbits (rats $>$ mice = rabbits, the highest to lowest nephrotoxicity), confirming the existence of subtle species differences. Since the usual human regimen of cisplatin injection has been shown to be 20 to $100 \mathrm{mg} / \mathrm{m}^{2}$ as a dosage level once daily for 1 to 5 days at intervals of 2 or 4 weeks (Chabner et al. 2006), the nephrotoxic doses obtained from these 3 species were fairly low compared to the human recommended clinical dose. The intensity of the renal Pt residue at the nephrotoxic dose of cisplatin was in the order of rabbits $>$ rats $>$ mice, unlike the order of the nephrotoxic potential. Although C-S lyase has been found in cytosolic, mitochondrial, and microsomal fractions of human kidney tissues, we selected a relatively highly pure mitochondrial fraction to clarify the linkage between AST activity and C-S lyase expression. The endogenous (basal) mitochondrial AST activity in the renal cortex of naive animals was in the order of rats $>$ mice $=$ rabbits, and expression of their GOT2 existed at approximately $37 \mathrm{kDa}$ in these species. The findings implied that mitochondrial AST activity would be at least associated with C-S lyase expression. In the additional study, a qualitative Western blot analysis using a combination of goat anti-GOT2 antibody and anti-goat IgG secondary antibody elicited the same expression as the mouse GOT2 antibody, confirming the reproducibility (data not shown).

Based on the current results, together with a proposed mechanism of cisplatin nephrotoxicity (Hanigan et al. 2009), the following explanation of species differences is offered. Among the animals tested, the rat was the most susceptible to cisplatin nephrotoxicity, presumably because toxic metabolite production was increased by both a high cortical Pt concentration and high mitochondrial AST (C-S lyase) activity. The mouse showed less nephrotoxic than the rat, probably because of lower toxic metabolites due to either a lower cortical Pt concentration or lower mitochondrial AST activity. In the rabbit, the mitochondrial AST activity was extremely low despite a high cortical Pt concentration, and accordingly the rabbit exhibited less nephrotoxicity than the rat. Alternatively, further studies are needed to quantitatively grasp the reactive (toxic) metabolites of cisplatin in the renal cortex. Generally, the rabbit is well known to possess high susceptibility to nephrotoxic agents including antibiotics compared with rats (Atkinson et al. 1966); therefore, this species is frequently used for early screening of novel pharmaceutical candidates. Our 
findings that cisplatin nephrotoxicity was stronger in rats than in rabbits were extremely interesting.

In the veterinary field, the use of cisplatin in the cat is contraindicated due to severe pulmonary edema with renal congestion (Knapp et al. 1987), unlike the dog. This species difference may be partially explained by our findings of apparently high cortical mitochondrial AST activity worked as a high C-S lyase in cats compared with dogs, which may lead to greater production of reactive metabolites.

In in vitro studies, expression of C-S lyase mRNA was significantly lower in rabbit cells than that in rat, cat, or dog cells (intensity of mRNA expression: cat $=\operatorname{dog}>$ rat $>$ rabbit). When the cytotoxicity of cisplatin was calculated using identical cells, the $\mathrm{IC}_{50}$ in rabbit cells was significantly higher than those in three other cells (cytotoxic potential: $c a t=d o g>$ rat $>$ rabbit). This suggests a positive association between C-S lyase mRNA levels and cytotoxicity. Treatment with AOAA protected against cisplatin cytotoxicity from concentration as low as $25 \mu \mathrm{M}$ only in rabbit cells, possibly owing to their low level of C-S lyase mRNA and mild cytotoxicity. These results strongly indicate that the cytotoxic potential of cisplatin is dependent on the quantity of C-S lyase in cells. In contrast to our results, one in vitro study found no evidence of $\mathrm{C}-\mathrm{S}$ lyase/glutamine transaminase $\mathrm{K}$ inhibition following AOAA treatment (Wainford et al. 2009). It is possible that different C-S lyase mRNA expression levels in cells used in vitro studies may produce different results with respect to C-S lyase inhibition and cisplatin cytotoxicity. Concerning the in vitro mouse study, we failed to culture a kidney cell-line originated from the mouse in the preliminary study. Since the above results were not related to species differences at which we aimed, we did not perform the further mouse study.

Our data support the proposed biotransformation mechanism by which cisplatin is transported, mainly by the transporter OCT2, into the proximal tubular epithelial cells and secreted into the proximal tubule lumen by MRP2, and then cleaved by the brush border enzyme GGT to create a Pt-cysteine-glycine conjugate, which is subsequently cleaved to a Pt-cysteine S-conjugate. The Pt-cysteine S-conjugates are reabsorbed via renal cysteine heterodimetric amino acid transporters into the proximal tubular epithelia, where they are metabolized by $\mathrm{C}-\mathrm{S}$ lyase to produce toxic reactive metabolites (Hanigan and Devarajan 2003; Townsend et al. 2003; Townsend and Hanigan 2002; Zhang et al. 2006; Zhang and Hanigan 2003).

In conclusion, the present results demonstrate that species differences in cisplatin nephrotoxicity are attributable to the interaction of renal Pt transition with C-S lyase activity.

\section{Conflict interest}

There are no conflicts of interest relating to the data presented in this paper.

\section{Acknowledgments}

We thank Prof. Kouichiro Sera, Cyclotron Research Center, Iwate Medical University, and Prof. Shigenao Kawai, Department of Food Science and Biochemistry, Iwate University, for excellent advice 
and generous suggestions for determining renal Pt concentrations. We acknowledge Dr. Hiroshi Satoh for performing the peer review of histopathological findings. This work was partially supported by a grant from Kita-Tohoku Three Universities (No. 12063745).

\section{References}

Atkinson, R.M., Currie, J.P., Davis, B., Pratt, D.A.H., Sharpe, H.M., Tomich, E.G., 1966. Acute toxicity of cephaloridine, an antibiotic derived from cephalosporin C. Toxicol. Appl. Pharmacol. 8, 398-406.

Chabner, B.A., Amrein, P.C., Druker, B., Michaelson, M.D., Mitsiades, C.S., Goss, P.E., Ryan, D.P., Ramachandra, S., Richardson, P.G., Supko, J.G., Wilson, W.H., 2006. Chemotherapy of neoplastic diseases, In: Brunton, L.L., Lazo, J.S., Parker, K.L. (Eds.), Goodman and Gilman's the pharmacological basis of therapeutics. 11th, McGraw-Hill, New York, pp. 1333-1334.

Cooper, A.J.L., Bruschi, S.A., Iriarte, A., Martinez-Carrion, M., 2002. Mitochondrial aspartate aminotransferase catalyses cysteine S-conjugate $\beta$-lyase reactions. Biochem. J. 368, 253-261.

Cooper, A.J.L., Meister, A., 1985. Glutamine transaminase K from rat kidney. Methods Enzymol. 113, 344-349.

Cooper, A.J.L., Pinto, J.T., 2006. Cysteine S-conjugate $\beta$-lyases. Amino Acids 30, 1-15.

Cvitkovic, E., 1998. Cumulative toxicities from cisplatin therapy and current cytoprotective measures. Cancer Treat. Rev. 24, 265-281.

Dickey, D.T., Muldoon, L.L., Doolittle, N.D., Peterson, D.R., Kraemer, D.F., Neuwelt, E.A., 2008. Effect of $\mathrm{N}$-acetylcysteine route of administration on chemoprotection against cisplatin-induced toxicity in rat models. Cancer Chemother. Pharmacol. 62, 235-241.

Dickey, D.T., Wu, Y.J., Muldoon, L.L., Neuwelt, E.A., 2005. Protection against cisplatin-induced toxicities by $\mathrm{N}$-acetylcysteine and sodium thiosulfate as assessed at the molecular, cellular, and in vivo levels. J. Pharmacol. Exp. Ther. 314, 1052-1058.

Giaccone, G., 2000. Clinical perspectives on platinum resistance. Drugs 59, 9-17.

Hanigan, M.H., Devarajan, P., 2003. Cisplatin nephrotoxicity: molecular mechanisms. Cancer Ther. 1, 47-61.

Hanigan, M.H., Townsend, D.M., Cooper, A.J.L., 2009. Metabolism of cisplatin to a nephrotoxin. Toxioclogy 257, 174-175.

Japanese Association for Laboratory Animal Science, 1987. Guidelines for animal experimentation. Exp. Anim. 3, 285-288.

Kai, K., Satoh, H., Yoshida, M., Suzuki, T., Shikanai, Y., Kajimura, T., Furuhama, K., 2006, Species and sex differences in susceptibility to olfactory lesions among the mouse, rat and monkey following an intravenous injection of vincristine sulphate. Toxicol. Pathol. 34, 223-231.

Knapp, D.W., Richardson, R.C., DeNicola, D.B., Long, G.G., Blevins, W.E., 1987. Cisplatin toxicity in 
cats. J. Vet. Intern. Med. 1, 29-35.

Lokich, J., Anderson, N., 1998. Carboplatin versus cisplatin in solid tumors: an analysis of the literature. Ann. Oncol. 9, 13-21.

Ludwig, T., Riethmüller, C., Gekle, M., Schwerdt, G., Oberleithner, H., 2004. Nephrotoxicity of platinum complexes is related to basolateral organic cation transport. Kidney Int. 66, 196-202.

Pinzani, V., Bressolle, F., Haug, I.J., Galtier, M., Blayac, J.P., Balmès, P., 1994. Cisplatin-induced renal toxicity and toxicity-modulating strategies: a review. Cancer Chemother. Pharmacol. 35, 1-9.

Sagara-Ishijima, N., Furuhama, K., 1999. Toxic characteristics of the synthetic lipid A derivatives DT-5461 in rats and monkeys. Toxicol. Sci. 49, 324-331.

Tarloff, J.B., Goldstein, R.S., Hook, J.B., 1989. Strain differences in acetaminophen nephrotoxicity in rats: role of pharmacokinetics. Toxicology 56, 167-177.

Townsend, D.M., Deng, M., Zhang, L., Lapus, M.G., Hanigan, M.H., 2003. Metabolism of cisplatin to a nephrotoxin in proximal tubule cells. J. Am. Soc. Nephrol. 14, 1-10.

Townsend, D.M., Hanigan, M.H., 2002. Inhibition of $\gamma$-glutamyl transpeptidase or cysteine S-conjugate $\beta$-lyase activity blocks the nephrotoxicity of cisplatin in mice. J. Pharmacol. Exp. Ther. 300, $142-148$.

Tsuchiya, Y., Takahashi, Y., Jindo, T., Furuhama, K., Suzuki, K.T., 2003. Comprehensive evaluation of canine renal papillary necrosis induced by nefiracetam, a neurotransmission enhancer. Eur. J. Pharmacol. 475, 119-128.

U. S. Department of Health and Human Services, Food and Drug Administration, Center for Drug Evaluation and Research (FDA-CDER), 2005. Guidance for industry. Estimating the maximum safe starting dose in initial clinical trials for therapeutics in adult healthy volunteers. Announced in the Federal Register 70, July 22.

Wainford, R.D., Weaver, R.J., Stewart, K.N., Brown, P., Hawksworth, G.M., 2008. Cisplatin nephrotoxicity is mediated by gamma glutamyltranspeptidase, not via a C-S lyase governed biotransformation pathway. Toxicology 249, 184-193.

Wainford, R.D., Weaver, R.J., Stewart, K.N., Brown, P., Hawksworth, G.M., 2009. Metabolism of cisplatin to a nephrotoxin. Toxicology 257, 176-177.

Zhang, L., Cooper, A.J.L., Krasnikov, B.F., Xu, H., Bubber, P., Pinto, J.T., Gibson, G.E., Hanigan, M.H., 2006. Cisplatin-induced toxicity is associated with platinum deposition in mouse kidney mitochondria in vivo and with selective inactivation of the alpha-ketoglutarate dehydrogenase complex in LLC-PK1 cells. Biochemistry 45, 8959-8971.

Zhang, L., Hanigan, M.H., 2003. Role of cysteine S-conjugate $\beta$-lyase in the metabolism of cisplatin. J. Pharmacol. Exp. Ther. 306, 988-994. 


\section{Figure Legends}

Fig. 1 Representative histopathological findings in the kidney of rats given cisplatin $\left(45 \mathrm{mg} / \mathrm{m}^{2}\right)$ alone or in combination with AOAA (100 mg/kg). AOAA was orally administered 30 and 60 min before an intravenous injection of cisplatin. Severe necrosis with pyknotic epithelial cells (arrows) was observed with cisplatin alone (A). These alterations were ameliorated by pretreatment with AOAA (B). H-E staining, Bars $=100 \mu \mathrm{m}$

Fig. 2 Endogenous mitochondrial AST activity (A) and Western blot analysis (B) of cortical C-S lyase in the kidney of naive mice, rats, rabbits, cats and dogs. For the Western blot analysis, mitochondria fractions were immunoblotted with mouse anti-human GOT2 antibody. The molecular weight (MW) of C-S lyase was approximately $37 \mathrm{kDa}$. AST activity is represented as means $\pm \mathrm{SD}$ of 5-6 animals. $* p<$ 0.05: significant difference from values for mice (Dunnett's test). The representative Western blot is selected among the 3 independent experiments.

Fig. 3 Expression of C-S lyase mRNA (A) and cytotoxic potentials ( $\mathrm{IC}_{50}$ values) of cisplatin (B) in intact renal cells from the rat, rabbit, cat and dog. Real-time reverse transcriptase-PCR was performed with C-S lyase mRNA from the respective intact cells. The amounts of mRNA were normalized to GAPDH mRNA. Values are represented as means \pm SD of three independent experiments. $* * p<0.01$ : significant difference from values for rats (Dunnett's test). In the evaluation of cytotoxic potential, cisplatin was incubated with the respective cells at $37^{\circ} \mathrm{C}$ for $3 \mathrm{~h}$. The calculated $\mathrm{IC}_{50}$ values are represented as means \pm SD of 5-6 experiments. $* * p<0.01$ : significant difference from values for rats (Dunnett's test).

Fig. 4 Protective effect of AOAA against cisplatin cytotoxicity in rabbit cells. Cisplatin at $\mathrm{IC}_{50}(180$ $\mu \mathrm{M})$ and $\operatorname{AOAA}(25-100 \mu \mathrm{M})$ were incubated with the cells at $37^{\circ} \mathrm{C}$ for $30 \mathrm{~min}$. Cells exposed to the conditioned medium alone served as the control. The survival rate is represented as means \pm SD of 4-6 experiments $* * p<0.01$ : significant difference from the control (Student's $t$-test). $\dagger \dagger p<0.01$ : significant difference from cisplatin alone (Dunnett's test). 
Table 1 Oligonucleotide primers used for real-time PCR

\begin{tabular}{ccccc}
\hline Gene & Accession No. & Primer & Sequence & Position \\
\hline GOT2 & \multirow{2}{*}{ NM_013177 } & Forward & 5'-TGCCAATCCTATGCCAAGAACA-3' & 909-930 \\
& & Reverse & 5'-CTTCTGCATCTTTGCAGACCACA-3' & 965-984 \\
GAPDH & \multirow{2}{*}{ NM_017008 } & Forward & 5'-GGCACAGTCAAGGCTGAGAATG-3' & 242-263 \\
& & Reverse & 5'-ATGGTGGTGAAGACGCCAGTA-3' & 364-384 \\
\hline
\end{tabular}


Table 2 Clinicopathological findings on day 5 in male rats given intravenously cisplatin alone or in combination with oral aminooxyacetic acid (AOAA)

\begin{tabular}{|c|c|c|c|c|c|c|c|}
\hline \multirow[b]{2}{*}{ Group } & \multirow[b]{2}{*}{ Dose } & \multirow{2}{*}{$\begin{array}{l}\text { Body weight } \\
(\mathrm{g}) \\
\end{array}$} & \multirow[b]{2}{*}{ Mortality } & \multirow{2}{*}{$\begin{array}{c}\text { Serum } \\
\text { creatinine } \\
(\mathrm{mg} / \mathrm{dl})\end{array}$} & \multicolumn{2}{|c|}{$\begin{array}{l}\text { Necrotic scores in renal } \\
\text { proximal epithelial cells }\end{array}$} & \multirow{2}{*}{$\begin{array}{l}\text { Renal cortical Pt } \\
\text { residue } \\
(\mu \mathrm{g} / \mathrm{g}) \\
\end{array}$} \\
\hline & & & & & + & $2+$ & \\
\hline Control & Saline $10 \mathrm{~mL} / \mathrm{kg}+\mathrm{DW} 10 \mathrm{~mL} / \mathrm{kg}$ & $193.2 \pm 12.6$ & $0 / 5$ & $0.20 \pm 0.01^{b)}$ & $5^{\mathrm{c})}$ & 0 & BLQ \\
\hline AOAA alone & Saline $10 \mathrm{~mL} / \mathrm{kg}$ + AOAA $100 \mathrm{mg} / \mathrm{kg}$ & $174.4 \pm 7.5^{*}$ & $0 / 5$ & $0.21 \pm 0.01$ & 0 & 0 & BLQ \\
\hline Cisplatin alone & Cisplatin $45 \mathrm{mg} / \mathrm{m}^{2}+\mathrm{DW} 10 \mathrm{~mL} / \mathrm{kg}$ & $139.8 \pm 13.0^{* *}$ & $1 / 5$ & $3.03 \pm 1.06^{*}$ & 0 & 4 & $74.9 \pm 12.5$ \\
\hline Cisplatin + AOAA & Cisplatin $45 \mathrm{mg} / \mathrm{m}^{2}+$ AOAA 100 & $142.8 \pm 6.1 * *$ & $0 / 5$ & $1.04 \pm 0.20 * * \dagger$ & 4 & 0 & 70.2. \pm 5.8 \\
\hline
\end{tabular}

$B L Q$ : below the limit of qualification, Saline: $0.9 \%$ physiological saline, DW: distilled wate

AOAA was orally administered 30 and 60 min before an intravenous injection of cisplatin.

${ }^{\text {a) }}$ Grade, -: no change; \pm : slight; +: mild; $2+$ : moderate

b) Values show the mean \pm SD.

c) Number of animals showing lesions

$* P<0.05, * * P<0.01$ vs. control (Dunnett's test), $\dagger P<0.01$ vs. cisplatin alone (Student's t-test) 
Table 3 Clinicopathological findings on day 5 in male mice, rats and rabbits given a single intravenous injection of cisplatin

\begin{tabular}{|c|c|c|c|c|c|c|c|c|c|c|}
\hline \multirow[b]{2}{*}{ Species } & \multirow{2}{*}{$\begin{array}{c}\text { Dose } \\
\left(\mathrm{mg} / \mathrm{m}^{2}\right)\end{array}$} & \multirow[b]{2}{*}{ Body weight ${ }^{\text {b) }}$} & \multirow[b]{2}{*}{ Mortality } & \multirow{2}{*}{$\begin{array}{c}\text { Serum } \\
\text { creatinine } \\
(\mathrm{mg} / \mathrm{dl})\end{array}$} & \multicolumn{5}{|c|}{$\begin{array}{c}\text { Necrotic score of renal } \\
\text { proximal epithelial cells }\end{array}$} & \multirow{2}{*}{$\begin{array}{l}\text { Renal cortical Pt residue } \\
\qquad(\mu \mathrm{g} / \mathrm{g})\end{array}$} \\
\hline & & & & & - & \pm & + & $2+$ & $3+$ & \\
\hline \multirow{4}{*}{ Mice } & Control & $20.5 \pm 0.8$ & $0 / 5$ & $0.07 \pm 0.01^{\mathrm{c})}$ & $5^{\text {d) }}$ & 0 & 0 & 0 & 0 & BLQ \\
\hline & 22.5 & $19.7 \pm 1.1$ & $0 / 5$ & $0.09 \pm 0.07$ & 5 & 0 & 0 & 0 & 0 & $10.5 \pm 1.8$ \\
\hline & 45 & $16.5 \pm 1.3^{* *}$ & $0 / 5$ & $0.18 \pm 0.11$ & 2 & 2 & 1 & 0 & 0 & $16.0 \pm 5.1$ \\
\hline & 90 & $16.9 \pm 0.9 * *$ & $2 / 5$ & $2.04 \pm 0.72 *$ & 0 & 0 & 2 & 1 & 0 & $31.0 \pm 4.7$ \\
\hline \multirow{5}{*}{ Rats } & Control & $189.7 \pm 7.6$ & $0 / 5$ & $0.23 \pm 0.02$ & 5 & 0 & 0 & 0 & 0 & BLQ \\
\hline & 11.3 & $180.0 \pm 5.3$ & $0 / 5$ & $0.23 \pm 0.01$ & 5 & 0 & 0 & 0 & 0 & $11.0 \pm 4.8$ \\
\hline & 22.5 & $168.8 \pm 9.9 *$ & $0 / 5$ & $0.56 \pm 0.15^{*}$ & 0 & 0 & 0 & $4^{\mathrm{e})}$ & 0 & $26.8 \pm 5.3$ \\
\hline & 45 & $144.4 \pm 5.1 * *$ & $0 / 5$ & $2.39 \pm 0.32 *$ & 0 & 0 & 1 & & 0 & $60.0 \pm 8.5$ \\
\hline & 90 & ND & $5 / 5$ & ND & 0 & 0 & 0 & $1^{\mathrm{f})}$ & 0 & 128.9 \\
\hline \multirow{6}{*}{ Rabbits } & Control & $2.70 \pm 0.14$ & $0 / 3$ & $0.78 \pm 0.03$ & 3 & 0 & 0 & 0 & 0 & BLQ \\
\hline & 12 & $2.68 \pm 0.23$ & $0 / 3$ & $0.82 \pm 0.05$ & 3 & 0 & 0 & 0 & 0 & $19.8^{\mathrm{g})}$ \\
\hline & 24 & $2.69 \pm 0.24$ & $0 / 3$ & $0.94 \pm 0.06$ & 3 & 0 & 0 & 0 & 0 & 31.1 \\
\hline & 48 & $2.27 \pm 0.18^{* *}$ & $0 / 3$ & $9.46 \pm 1.03 * *$ & 0 & 0 & 1 & 2 & 0 & 81.7 \\
\hline & 96 & $2.00 \pm 0.18^{* *}$ & $0 / 3$ & $14.10 \pm 1.95^{* *}$ & 0 & 0 & 0 & 1 & 2 & 176.2 \\
\hline & 192 & ND & $2 / 2$ & ND & & & & & & \\
\hline
\end{tabular}

$B L Q$ : below the limit of qualification, ND: no data

a) Grade, -: no change; \pm : slight; +:mild; 2+: moderate; $3+$ : severe

b) The unit of body weight is $\mathrm{g}$ for mice and rats, and $\mathrm{kg}$ for rabbits.

c) Values show the mean \pm SD.

d) Number of animals showing lesions

e) One animal was excluded because of the technical error of the tissue preparation.

${ }^{\mathrm{f})}$ One moribund animal was included.

g) The number of animals was 2 , because of accidentally technical errors. Values show the mean.

$* P<0.05, * * P<0.01$ vs. control in each species (Dunnett's test) 
Table 2 Clinicopathological findings on day 5 in male rats given intravenously cisplatin alone or in combination with oral aminooxyacetic acid (AOAA)

\begin{tabular}{|c|c|c|c|c|c|c|c|c|}
\hline \multirow[b]{2}{*}{ Group } & \multirow[b]{2}{*}{ Dose } & \multirow[b]{2}{*}{ Mortality } & \multirow{2}{*}{$\begin{array}{c}\text { Serum } \\
\text { creatinine } \\
(\mathrm{mg} / \mathrm{dl}) \\
\end{array}$} & \multicolumn{4}{|c|}{$\begin{array}{c}\text { Necrotic scores in renal } \\
\text { proximal epithelial }\end{array}$} & \multirow{2}{*}{$\begin{array}{c}\text { Renal cortical } \mathrm{Pt} \\
\text { residue } \\
(\mu \mathrm{g} / \mathrm{g})\end{array}$} \\
\hline & & & & - & \pm & + & $2+$ & \\
\hline Control & $\begin{array}{l}\text { Saline } 10 \mathrm{~mL} / \mathrm{kg} \\
+\mathrm{DW} 10 \mathrm{~mL} / \mathrm{kg}\end{array}$ & $0 / 5$ & $0.20 \pm 0.01^{b)}$ & $5^{c)}$ & 0 & 0 & 0 & BLQ \\
\hline AOAA alone & $\begin{aligned} & \text { Saline } 10 \mathrm{~mL} / \mathrm{kg} \\
+ & \text { AOAA } 100 \mathrm{mg} / \mathrm{kg}\end{aligned}$ & $0 / 5$ & $0.21 \pm 0.01$ & & & 0 & 0 & BLQ \\
\hline Cisplatin alone & $\begin{array}{l}\text { Cisplatin } 45 \mathrm{mg} / \mathrm{m}^{2} \\
\text { + DW } 10 \mathrm{~mL} / \mathrm{kg}\end{array}$ & $1 / 5$ & 3.0 & & 0 & 0 & 4 & $74.9 \pm 12.5$ \\
\hline Cisplatin + AOAA & $\begin{array}{l}\text { Cisplatin } 45 \mathrm{mg} / \mathrm{m}^{2} \\
+ \text { AOAA } 100 \mathrm{mg} / \mathrm{kg}\end{array}$ & $0 / 5$ & $1.04 \pm 0.20 * * \dagger$ & 0 & 1 & 4 & 0 & 70.2. \pm 5.8 \\
\hline
\end{tabular}

$B L Q$ : below the limit of qualification, Saline: $0.9 \%$ physiological saline, DW: distilled water

AOAA was orally administered 30 and $60 \mathrm{~min}$ before an intravenous injection of cisplatin.

a) Grade, -: no change; \pm : slight; +: mild; $2+$ : moderate

b) Values show the mean \pm SD.

c) Number of animals showing lesions

$* P<0.05, * * P<0.01$ vs. control (Dunnett's test), $\dagger P<0.01$ vs. cisplatin alone (Student's t-test) 
Table 3 Clinicopathological findings on day 5 in male mice, rats and rabbits given a single intravenous injection of cisplatin

\begin{tabular}{|c|c|c|c|c|c|c|c|c|c|}
\hline \multirow[b]{2}{*}{ Species } & \multirow{2}{*}{$\begin{array}{c}\text { Dose } \\
\left(\mathrm{mg} / \mathrm{m}^{2}\right)\end{array}$} & \multirow[b]{2}{*}{ Mortality } & \multirow{2}{*}{$\begin{array}{l}\text { Serum } \\
\text { creatinine } \\
(\mathrm{mg} / \mathrm{dl})\end{array}$} & \multicolumn{5}{|c|}{$\begin{array}{l}\text { Necrotic score of renal } \\
\text { proximal epithelial }\end{array}$} & \multirow{2}{*}{$\begin{array}{c}\text { Renal cortical } \mathrm{Pt} \\
\text { residue } \\
(\mu \mathrm{g} / \mathrm{g})\end{array}$} \\
\hline & & & & - & \pm & + & $2+$ & $3+$ & \\
\hline \multirow{4}{*}{ Mice } & Control & $0 / 5$ & $0.07 \pm 0.01^{\mathrm{b})}$ & $5^{c)}$ & 0 & 0 & 0 & 0 & $\mathrm{BLQ}$ \\
\hline & 22.5 & $0 / 5$ & $0.09 \pm 0.07$ & 5 & 0 & 0 & 0 & 0 & $10.5 \pm 1.8$ \\
\hline & 45 & $0 / 5$ & $0.18 \pm 0.11$ & 2 & 2 & 1 & 0 & 0 & $16.0 \pm 5.1$ \\
\hline & 90 & $2 / 5$ & $2.04 \pm 0.72 *$ & 0 & 0 & 2 & 1 & 0 & $31.0 \pm 4.7$ \\
\hline \multirow{5}{*}{ Rats } & Control & $0 / 5$ & $0.23 \pm 0.02$ & 5 & 0 & 0 & 0 & 0 & BLQ \\
\hline & 11.3 & $0 / 5$ & $0.23 \pm 0.01$ & 5 & 0 & 0 & 0 & 0 & $11.0 \pm 4.8$ \\
\hline & 22.5 & $0 / 5$ & $0.56 \pm 0.15^{*}$ & 0 & 0 & 0 & $4^{d)}$ & 0 & $26.8 \pm 5.3$ \\
\hline & 45 & $0 / 5$ & $2.39 \pm 0.32 *$ & 0 & 0 & 1 & 4 & 0 & $60.0 \pm 8.5$ \\
\hline & 90 & $5 / 5$ & ND & 0 & 0 & 0 & $1^{\mathrm{e})}$ & 0 & 128.9 \\
\hline \multirow{6}{*}{ Rabbits } & Control & $0 / 3$ & $0.78 \pm 0.03$ & 3 & 0 & 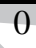 & 0 & 0 & BLQ \\
\hline & 12 & $0 / 3$ & $0.82 \pm 0.05$ & 3 & 0 & 0 & 0 & 0 & $19.8^{\mathrm{f})}$ \\
\hline & 24 & $0 / 3$ & $0.94 \pm 0.06$ & 3 & 0 & 0 & 0 & 0 & 31.1 \\
\hline & 48 & $0 / 3$ & $9.46 \pm 1.03 * *$ & 0 & 0 & 1 & 2 & 0 & 81.7 \\
\hline & 96 & $0 / 3$ & $14.1 \pm 1.95^{* *}$ & 0 & 0 & 0 & 1 & 2 & 176.2 \\
\hline & 192 & $2 / 2$ & ND & & & & & & \\
\hline
\end{tabular}

$B L Q$ : below the limit of qualification, ND: no data

${ }^{\text {a) }}$ Grade, -: no change; \pm : slight; +:mild; 2+: moderate; 3+: severe

b) Values show the mean $\pm \mathrm{SD}$

c) Number of animals showing lesions

d) One animal was excluded because of the technical error of the tissue preparation.

e) One moribund animal was included.

f) The number of animals was 2 , because of accidentally technical errors. Values show the mean.

$* p<0.05$ vs. control in each species (Dunnett's test) 

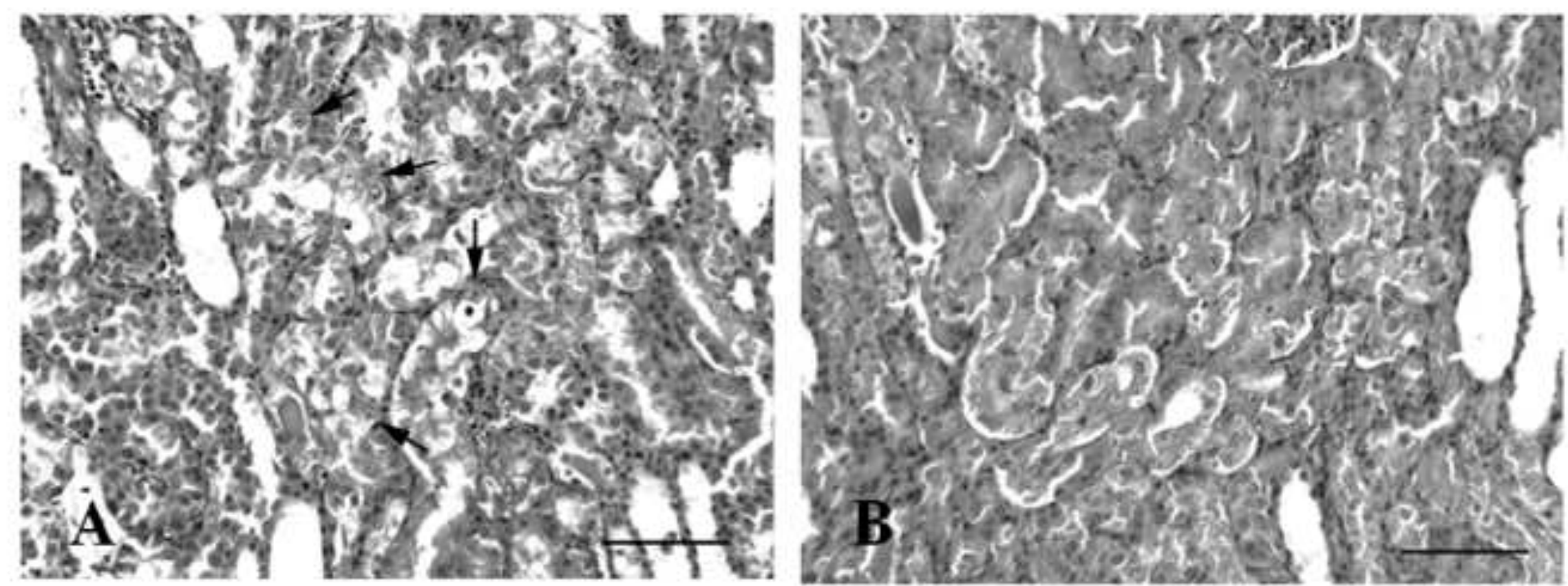

Fig. 1 

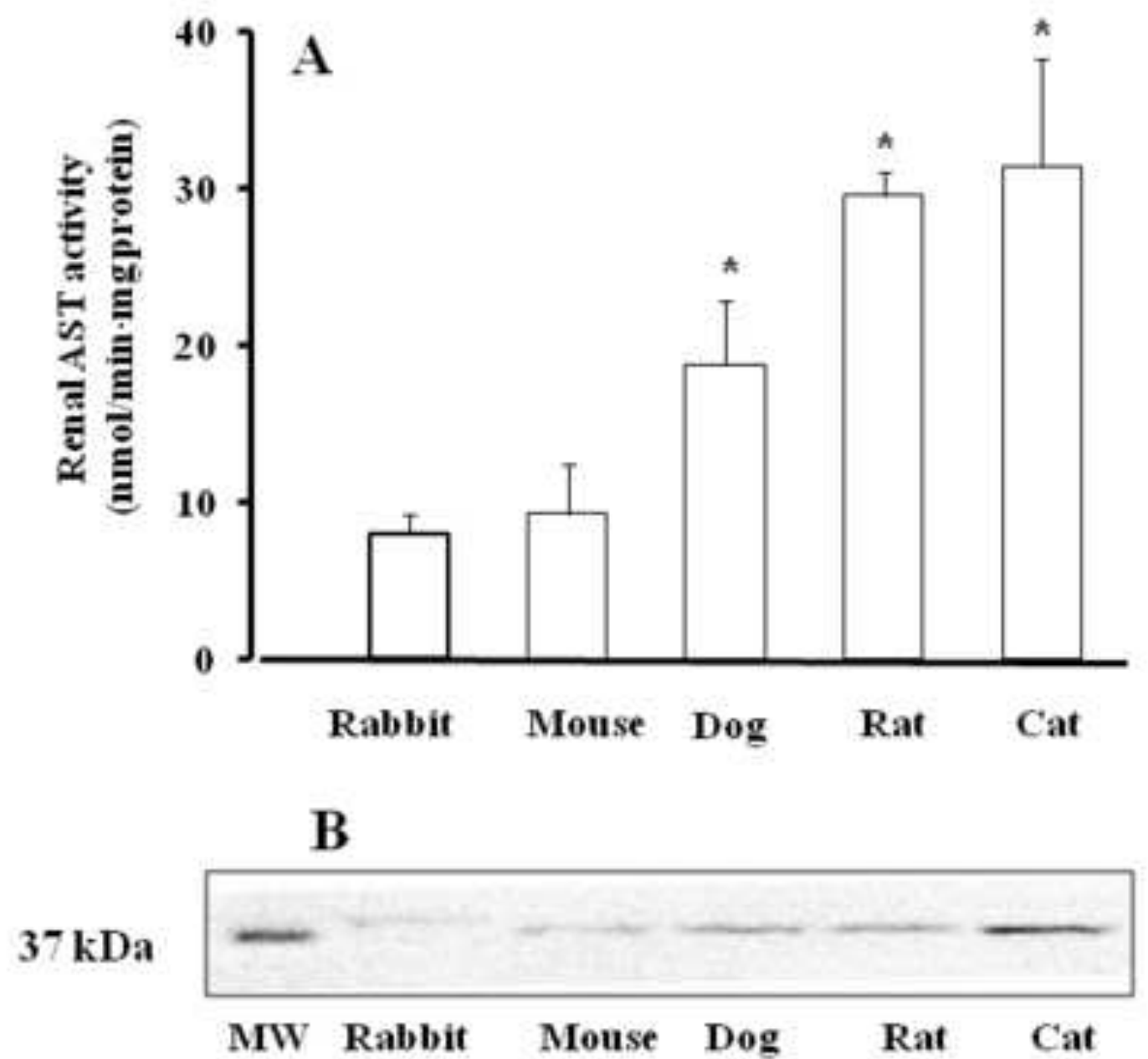

Fig. 2 

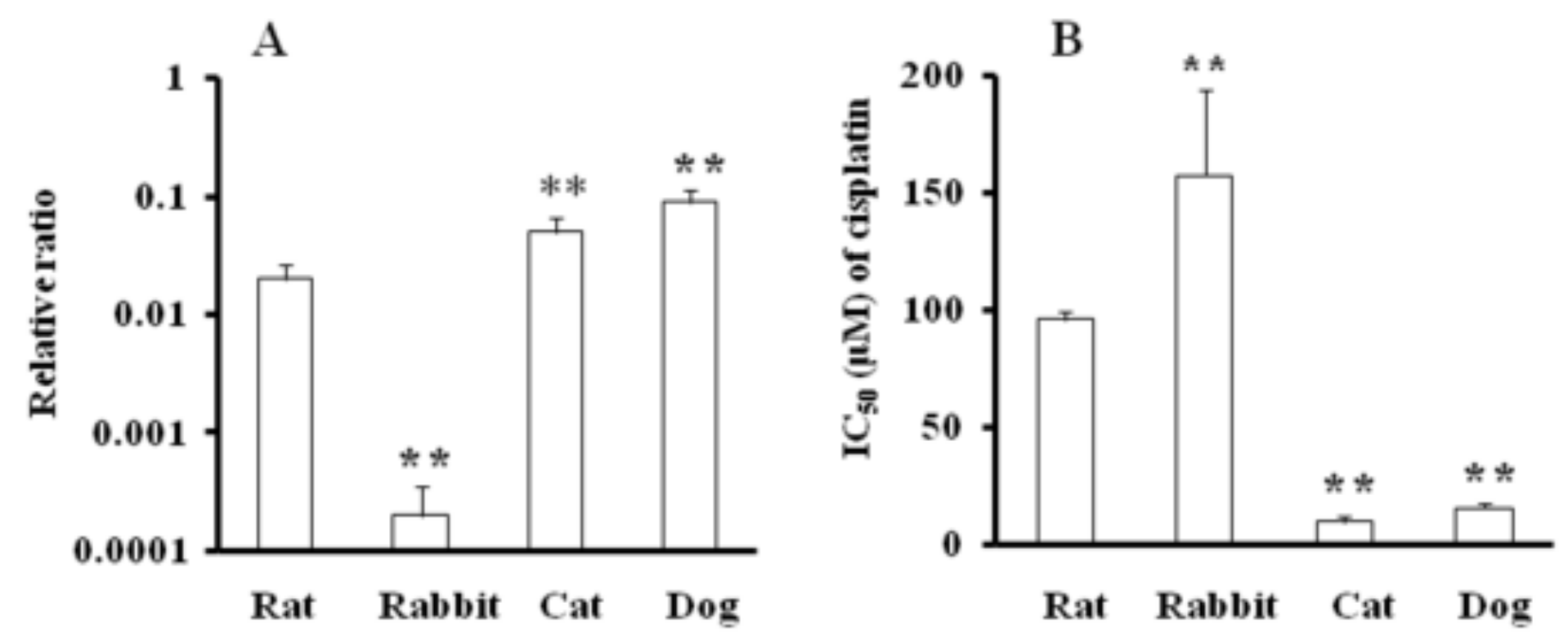

Fig. 3 


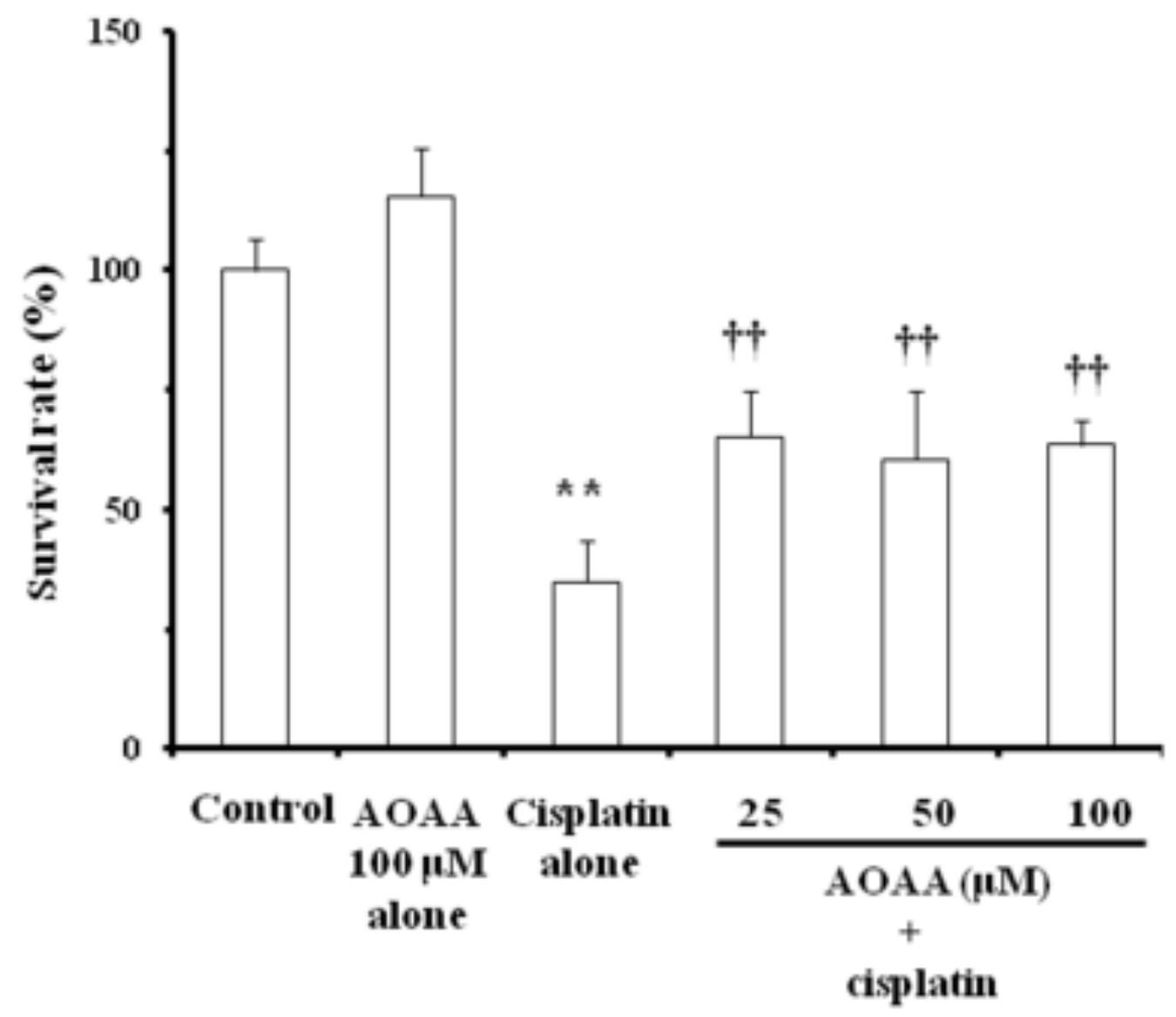

Fig. 4 
$<$ Highlights $>$

$>$ We studied on species differences in cisplatin nephrotoxicity using several animals. $>$ We confirmed the protective action of the C-S lyase inhibitor AOAA on cisplatin nephrotoxicity. $>$ The order of its nephrotoxic potentials was consistent with that of endogenous mitochondrial AST activities in the kidney. $>$ The cytotoxic potential of cisplatin was dependent on the expression level of C-S lyase mRNA in the in vitro system. > Species differences in cisplatin nephrotoxicity were related to an interaction of renal Pt transition with C-S lyase activity. 